Gerión. Revista de Historia Antigua

ISSN: 0213-0181

\title{
La democracia de Teseo, modelo de la Atenas del siglo IV a.C. y del imperio de los Antoninos. La Atidografía y Plutarco
}

\author{
Domingo Plácido Suárez ${ }^{1}$
}

Recibido: 20 de marzo de 2019 / Aceptado: 12 de junio de 2019

Resumen. La Atidografía es el género que más claramente procede a una invención del pasado para dar sentido a la situación presente como si estuviera arraigada en el pasado más prestigioso de Atenas. Para ello resulta de gran eficacia la figura de Teseo, en cuya tradición se encuentran elementos de gran utilidad para enmascarar los problemas del siglo IV a.C. En el Alto Imperio, Plutarco contribuye a la recuperación del pasado adaptado a los intereses de los emperadores filohelenos.

Palabras clave: Atidografía; Teseo; crisis; Plutarco; Antoninos.

\section{[en] Theseus' Democracy, a Model for Fourth-Century Athens and for the Empire of the Antonines}

Summary. Among the literary genres, Attidography is the one most clearly devoted to the construction of the past in order to interpret the present as rooted in the most prestigious past of Athens. Theseus seems instrumental to that effort, a hero whose traditions provide useful material to conceal the troubles of the IV century BC. On the other hand, Plutarch contributes during the Early Empire to recover a vision of the past adapted to the interests of the emperors.

Keywords: Attidography; Theseus; Crisis; Plutarch; Antonines.

Sumario. 1. Introducción. 2. La tradición de Teseo. 3. La Atidografía. 4. La imagen del pasado en el siglo IV a.C. 5. Plutarco: época imperial. 6. Referencias bibliográficas.

Cómo citar: Plácido, D. (2019): La democracia de Teseo, modelo de la Atenas del siglo IV a.C. y del imperio de los Antoninos. La Atidografía y Plutarco, en Gerión 37/2, 301-321.

$1 \quad$ Universidad Complutense de Madrid.

E-mail: placido@ghis.ucm.es 


\section{Introducción ${ }^{2}$}

Posiblemente el género historiográfico en el que se configura de modo más preciso la práctica de la invención del pasado es la Atidografía, como parte específica de la Historiografía, con importantes derivaciones tanto en la oratoria como en obras del tipo de la Constitución de los atenienses de la escuela aristotélica, que seguramente utilizó como fuente principal a Androción, autor de Atthis ${ }^{3}$ los capítulos referidos al Arcaísmo suelen atribuirse a tales fuentes. El capítulo 4 refleja por parte de Aristóteles la consideración de todo lo narrado como hipotético, ${ }^{4}$ posteriormente, también se usa en las biografías de Plutarco: éste menciona -entre otros- a Filócoro como uno de los que ganaron gloria al exponer las hazañas de otros, contribuyendo así a la gloria de los atenienses. ${ }^{5}$ Para Mazzarino, el precedente de la Atidografía habría que buscarlo en la Orestía. ${ }^{6}$

Helánico de Lesbos fue autor de Atthis, modelo de otras Atthides de los siglos IV y III a.C. Data por arcontes, sistema que critica Tucídides $;{ }^{7}$ recoge tradiciones locales atenienses y narraciones míticas como la de Cadmo y los dientes del dragón; ${ }^{8}$ inserta, pues, los mitos en las historias. La función de la invención aparece en Platón como "nobles mentiras capaces de persuadir a los gobernantes". 9 Según Filócoro, Solón y Platón señalan un proverbio: "mucho mienten los aedos"; los poetas mienten desde que se establecieron $\tilde{\alpha} \theta \lambda \alpha$ en los festivales, pero antes decían la verdad. ${ }^{10}$ Hay, pues, una polémica sobre la veracidad, en la que intervienen los atidógrafos.

En este artículo se trata de analizar cómo la tradición de Teseo se convierte en instrumento de propaganda de la democracia restaurada del siglo IV a.C. y luego de la política panhelénica de Adriano.

\section{La tradición de Teseo}

La tradición de Teseo proviene de varias leyendas locales unificadas hacia el siglo VI a.C. en relación con la formación de la ciudad, factor básico en la creación de dicha tradición. Plutarco, por su parte, vive en la época de los Antoninos; en la Vida de Teseo reconoce que se introduce en un terreno propio de mitólogos y

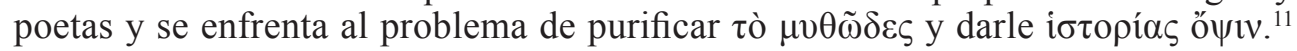
Recuerda la afirmación de Hesíodo sobre la Musas, ${ }^{12}$ que dicen verdades, pero también falsedades que pasan por verdades. Plutarco trata de obtener la verdad de

2 Agradezco a los informantes anónimos las correcciones que han evitado errores, así como las consideraciones que muestran la atención prestada y el profundo conocimiento del tema, digno de desarrollarse en trabajos independientes. Abreviaturas empleadas: $E G M=$ Fowler 2000; $F G H=$ Jacoby 1962 (detrás de las siglas $F G H$ se indica el número correspondiente al autor y después de $\mathrm{F}$ el número del fragmento citado).

3 Ver Harding 1994, vii, que lo considera el modelo de la Atidografía.

4 Bernabé 2005.

$5 \quad$ Así como en De gloria Atheniensium 1 = Mor. 345E. En Plutarco, el título del capítulo es: “¿Eran los atenienses más ilustres en la guerra o en la sabiduría?".

Mazzarino 1974, II 1, 78.

Th. 5.20.2.

$F G H 4$ = EGM 147-231; frg. 1ab; T19 = Str. 1.2.35.

R. 414BC. Saxonhouse 1986, 253.

Philoch. F1; Schol. Plat. De iusto, 374a. Puede ser una crítica contra Demón (Costa 2007).

Plu. Thes. 1.3 y 1.5 , respectivamente.

2 Hes. Th. 26-28. 
lo que se cuenta $\dddot{\eta} \kappa ı \tau \tau \alpha \tau \rho \alpha \gamma \iota \kappa \tilde{\omega} \zeta,{ }^{13}$ pero lo que sin duda consigue es una transmisión fidedigna de los elementos formativos del imaginario ateniense en la invención del propio pasado.

Teseo es presentado como de la estirpe de Erecteo, ${ }^{14}$ quien da nombre a una de las tribus de Clístenes. Por línea materna se remontaba a Pélope, origen de muchos reyes, pues casó a sus hijas con los más nobles, como Piteo, fundador de Trecén, abuelo de Teseo. Egeo recibió un oráculo sobre su descendencia en Atenas, interpretado por Piteo en el sentido de que se uniera con su hija Etra. Estos oráculos fueron difundidos en Atenas en la guerra del Peloponeso. ${ }^{15}$ Teseo dejó los signos de reconocimiento en una cueva; se oponían los hijos de Palante, hermano pequeño de

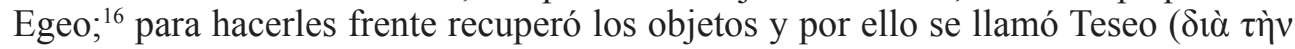

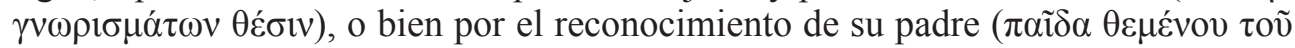
Ai $\gamma \varepsilon \dot{c}(\varsigma) .{ }^{17}$ Emprende un viaje iniciático a Delfos, propio de los que salían de la

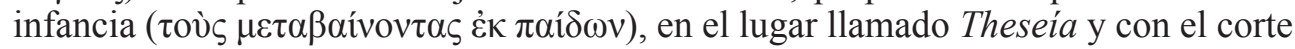
de pelo de los abantes de Eubea llamado $\Theta \eta \sigma \eta i_{\zeta},{ }^{18}$ adecuado para los guerreros, para que los enemigos no los agarraran por la cabellera. ${ }^{19}$ Habían dicho que era hijo de Posidón, a quien veneran los trecenios a veces como Posidón Egeo. ${ }^{20} \mathrm{La}$ corrección vendría de Plutarco, que no quiere mezclar divinidades y humanos, y se presenta como divinidad idéntica o afín a Posidón. ${ }^{21}$

Cuando reveló su fuerza y su inteligencia, a los dieciséis años, su madre lo condujo a los símbolos $(\sigma 0 ́ \mu \beta \mathrm{o} \lambda \alpha)$ de reconocimiento de su padre, escondidos bajo una piedra que levantó con facilidad, ${ }^{22} \mathrm{y}$ después a Atenas, a donde no quiso ir por mar, que era fácil, mientras el camino por tierra era peligroso. Era una época de hombres fuertes que aplicaban sus energías en la crueldad. Teseo rivalizaba con Heracles como Temístocles con Milcíades, pues Teseo y Heracles eran hijos de primos, descendientes de Pélope e Hipodamia. ${ }^{23}$ Así pues, Teseo se dedica a atacar a los malvados para emular a Heracles: ${ }^{24}$ mata a Perifetes, llamado Kopvví

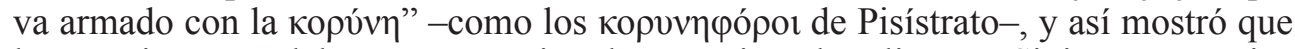
lo que importa del arma es quién la maneja; al aplicar a Sinis sus propios procedimientos de tortura muestra que la areté es superior a la téchne y la meléte; con su hija Perigune, que se había escondido, engendra a Melanipo, que se unirá con Eurito de Ecalia; de Melanipo y Perigune nacerá Yoxo, que con Órnito fundó colonias en Caria. Después aparece la cerda de Cromión, Fea, fiera femenina hija de Equidna

\footnotetext{
Plu. Thes. 2.3.

Plu. Thes. 3.1. Para Androción ( $F G H 324$ F54), Erecteo era padre de Egeo, padre de Teseo.

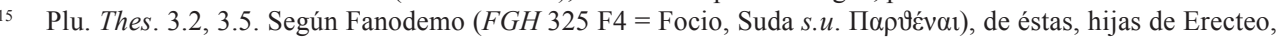
dos se sacrifican por la patria ( Pausanias trata el tema en 1.5.2 y 7.1.2-5; en 2.14.2, menciona el arreglo pacífico entre las dos póleis. Estrabón (8.7.1) dice que Eumolpo fue derrotado en una batalla. Véase Ampolo 1988; ver también Fontenrose 1978, 356 (nacimiento de Teseo contra la voluntad de los dioses, antes de convertirse en héroe nacional ateniense).

16 Plu. Thes. 3.7. Ver Flacelière 1957. Filócoro (F108) menciona a los Palántidas vencidos por Teseo.

17 Plu. Thes. 3.6, 3.7, 4.1.

18 Hom. Il. 5.542; Plu. Thes. 5.1.

19 Como menciona Arquíloco (frg. 9 Adrados = 3 Diehl - West); Plu. Thes. 5.2-4.

20 Plu. Thes. 6.1. Flacelière 1957.

22 Plu. Thes. 6.2. Como aparece en una imagen que hay en la Acrópolis (Paus. 1.27.8: $\gamma v \omega \rho i ́ \sigma \mu \alpha \tau \alpha)$.

23 Plu. Thes. 6.3, 6.4, 6.9, 7.1, 7.3.

24 Plu. Thes. 7.3. Perifetes: 8.1-2. Sinis: 8.3, 8.5-6. Cerda de Cromión: 9.1. Escirón: 10.1-4. Otros: 11.1.
}

21 Ampolo 1988. 
y Tifón..$^{25}$ Escirón lanzaba a los hombres desde las rocas o los oprimía y los lanzaba al mar. Los megarenses defienden que era un benefactor. Había tradiciones que lo relacionaban con personajes venerados en Atenas, como Circeo. Plutarco relaciona esta acción con la conquista de Mégara, pero reconoce que hay contradicciones en la tradición. Cuenta otras hazañas contra monstruos como Cerción o Procustes, a imitación de Heracles. Muestra también la sucesión adoptiva de Pandión a Egeo y de éste a Teseo. ${ }^{26}$

Con respecto al laberinto, Filócoro dice que era una prisión para los niños que servían de premio en los juegos establecidos por Minos, ${ }^{27}$ cuyo primer vencedor fue Tauro. ${ }^{28}$ Se ha destacado la tendencia racionalizadora de los atidógrafos -sobre todo de Filócoro- ${ }^{29}$ y de la recepción de Plutarco ${ }^{30}$ quien cita a Aristóteles diciendo que los niños habían sido sometidos a trabajos ( $\theta \eta \tau \varepsilon v ́ o v \tau \alpha \varsigma)$ y llevados a Yapigia y luego a Tracia. ${ }^{31}$ Minos se ha ganado el odio de Atenas aunque tiene fama de rey legislador. Presenta quejas contra el rey Egeo por dejar sacrificar a los hijos de los demás y preservar al suyo, bastardo y extranjero (vó $\theta \omega \kappa \alpha \grave{~} \xi \dot{\varepsilon} v \omega)$, pero Teseo se ofreció a incluirse entre las víctimas sin sorteo. ${ }^{32}$ Helánico dice que venía el mismo Minos a seleccionar a los jóvenes ${ }^{33}$ pero nadie lo relaciona con Salamina, salvo Filócoro. ${ }^{34}$ Tal vez el texto de Filócoro sobre Erecteo comprendía una digresión sobre Jon y el origen de las Boedromias. ${ }^{35}$ Como se ve, la historia tiene todos los rasgos que definen a los procesos iniciáticos del joven adaptados a la realeza.

A ello se añade el proceso de formación de la ciudad y de la ciudadanía. Aristóteles no cree que esto fuera una auténtica politeía, entendida como un régimen en el que predomina el hecho de poseer la ciudadanía, pues la primera como tal fue la que se produjo bajo Teseo, que se apartó un poco de la basiliké. Se trata de un sistema "sin rey" y con un centro definido por encima de las aldeas, según Plutarco. ${ }^{36}$ Existen otras tradiciones sobre la democracia de Teseo: ${ }^{37}$ Pausanias dice que ante la estoa de Zeus Eleuterio se encuentra la imagen de Democracia como obra de Teseo, pero él sabe que no era verdad, aunque también sabe que hay tradiciones que se creen, ${ }^{38}$ con lo que abunda en las consideraciones de Hesíodo, ya citadas. El oráculo vaticina la unidad en una polis: Teseo llama a todos a una ciudad en términos de

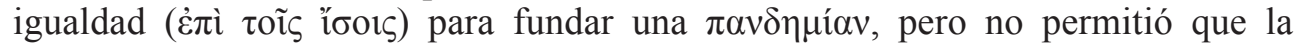

25 Apollod. Epit. 1.1. En Thes. 9.2, Plutarco usa una versión racionalizada tomada de Filócoro (FGH 328 F17). Véase Ampolo 1988 (quien lo toma de Flacelière 1957). Plutarco también racionalizaría la historia del Minotauro (Thes. 16.1).

26 Plu. Thes. 13.1. Para Fanodemo (F5), Egeo rey era hijo de Pandión. Androción (FGH 324 F60c $=$ Tzetzes a Licofrón, 494) dice que Egeo había nacido de Erecteo; Androción, entre otros, dice también que nació de los dientes de Tebas.

27 Filócoro (FGH 328 F17a, recogido en Plu. Thes. 15.2-7) cuenta la historia de Teseo y el laberinto, en texto muy parecido a F17b (= Eus. Chro. 785) y F17c.

28 Plu. Thes. 16.1.

29 Jacoby 1949, 133; Ampolo 1988.

30 Ampolo 1988, xiii-xvii. Bocaccio (Genealogia deorum gentilium 11.26) lo relaciona con el rapto de Europa. Todo parece remontarse a una tradición oral (légetai); cf. Costa 2007.

31 Plu. Thes. 16.2 .

32 Plu. Thes. 16.3-4, 17.1-3.

33 En Plu. Thes. 17.3.

34 Como aparece en Plutarco (Thes. 17.6-7 = F111; el F14, en cambio, se refiere a Eleusis).

35 Costa 2007, 148.

36 Plu. Thes. 24.2-3.

37 Musti 2000, 177.

38 Paus. 1.3.3. Munn 2000, 18. 
democracia fuera alterada (ó $\alpha \alpha \kappa \tau o v, \mu \varepsilon \mu 1 \gamma \mu \varepsilon ́ v \eta v)$ por la multitud de aluvión

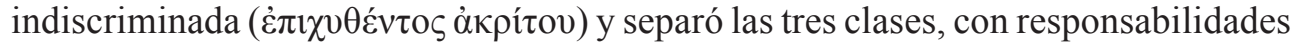
religiosas, políticas, legales y morales diferentes para los eupátridas en dignidad, utilidad y número. ${ }^{39} \mathrm{Es}$, pues, el primero que se inclinó hacia la multitud, como dice Aristóteles. ${ }^{40}$

Plutarco menciona una inscripción en que se señalaban los límites entre Mégara y Jonia, como nombre de Ática, según Estrabón, quien no menciona a Teseo, sino los límites de la época de Pandión, y cita a Filócoro, según el cual habría fijado los límites entre el Istmo y el Pitio. ${ }^{41}$ Pausanias recuerda a propósito de este texto el exilio de Céfalo, ${ }^{42}$ hijo de Deyón, nieto de Juto y Creúsa, que daría origen al nombre de Cefalenia; el santuario sería una etapa del viaje a Delfos en la vía sacra. ${ }^{43}$ Teseo inaugura nuevos juegos en honor de Posidón en el Istmo, en honor de Melicertes, quien se arrojó al mar entre Mégara y Corinto. Era primero una fiesta nocturna, teleté más que panegiria. ${ }^{44}$

Para Plutarco, el relato más verosímil es el que sitúa la expedición de Teseo después de la de Heracles, como hacen Ferécides, Helánico y Herodoro. ${ }^{45}$ Teseo, último rey de Atenas, había anteriormente raptado a Helena y también había hecho prisionera a la Amazona Antíope o la había recibido como géras en su expedición con Heracles al Ponto, según la narración de Plutarco. También cuenta Helánico la historia del rapto de Helena. ${ }^{46}$ Según Plutarco, nadie cuenta ninguna historia parecida

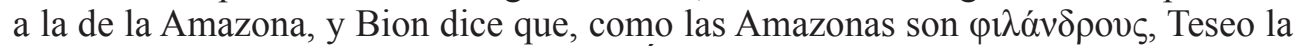
subió a la nave y, al subirse, àv $\alpha \chi \theta \tilde{\eta} v \alpha$. Él sí cree que las Amazonas acamparan en el centro de la ciudad, en la Pnix y el Museo, pues lo atestiguan los nombres de lugares: ${ }^{47}$ Clidemo habla de la acción en el ahora llamado Amazonio. ${ }^{48}$ Plutarco recoge una tradición muy elaborada del combate: Clidemo llama a Antíope Hipólita, que consiguió la paz; Plutarco reconoce que todo es muy incierto pero cree que muchas se enterraron en el Amazonio; la prueba para él está en el Horcomosio, cerca del santuario de Teseo donde se hace un sacrificio a las Amazonas. ${ }^{49}$ Plutarco habla con desdén de la Teseida, que trata de la muerte de las Amazonas por Heracles..$^{50}$ Hipólito era hijo de Antíope, Píndaro lo llama Demofonte. ${ }^{51}$ Sobre las desdichas de Teseo, los historiadores no contradicen a los trágicos. ${ }^{52}$ Según Fanodemo, es Demofonte quien recibe a Orestes en Atenas, frente a otras fuentes en que lo hace Pandión. ${ }^{53}$

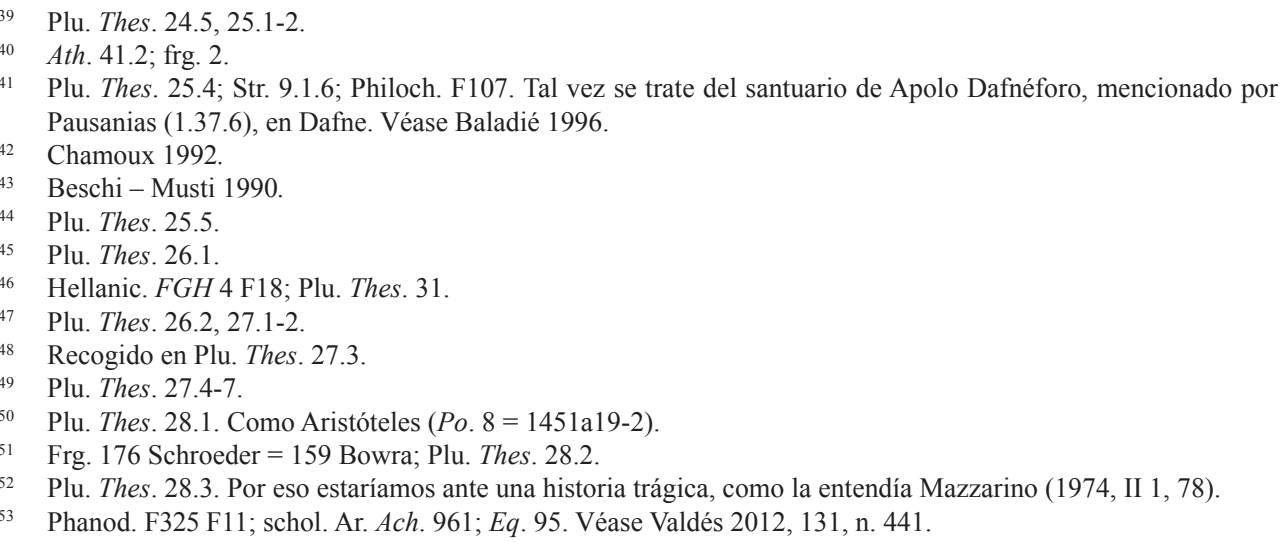


Menciona también Plutarco "cuentos sobre matrimonios" ( $\lambda$ ó

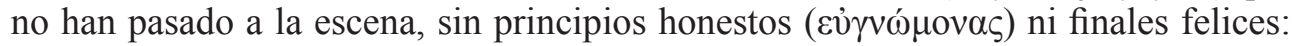

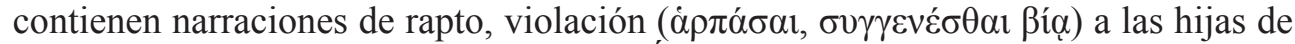
Cerción, y la boda con Peribea, madre de Áyax y con Ferebea y Yope, hija de Ificles, además de las historias amorosas con Egle, Ariadna y Helena, causa de la guerra en el Ática. ${ }^{54}$ Ateneo se refiere a Teseo entre los héroes con varias mujeres, mientras que

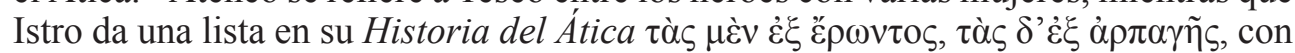
uso frecuente de este término y del verbo correspondiente (ö $\lambda \lambda \lambda_{\varsigma} \delta$ ' $\left.\dot{\varepsilon} \kappa v o \mu \mu^{\prime} \mu \omega v\right){ }_{.5}^{55}$ Plutarco señala las limitaciones de Teseo como héroe, "otro Heracles"; Herodoro sólo le atribuye la lucha de los lapitas con los centauros; otros añaden el viaje de Jasón o la lucha de Meleagro con el jabalí, no sin Teseo. ${ }^{56}$ Plutarco analiza aquí parcialmente el procedimiento de invención de la historia heroica que impregna todo este relato, cuajada de episodios de violación, como muchos lances en los que intervienen los dioses.

Atribuye Plutarco gran importancia a la amistad con Piritoo, $\varphi$ i $\lambda i \alpha$ nacida de la rivalidad y de la admiración mutua por la belleza y la audacia. Comparten con los lapitas la defensa de las mujeres frente a los centauros borrachos y dominados por la hýbris. La versión de Heliodoro introduce a Heracles en Traquis, descansando de los trabajos $(\tau \tilde{\omega} v \alpha \alpha \theta \lambda \omega v)$ y dice que se hicieron grandes alabanzas. Plutarco prefiere la versión de quienes relacionan la amistad con los procesos de iniciación y purificación. ${ }^{57}$ Helánico cuenta el rapto de Helena por Teseo con cincuenta años, pero hay quienes dicen que Teseo la rescató. Plutarco cree la versión de que Teseo y Piritoo la raptaron

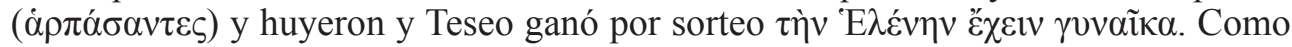
todavía no tenía edad, Teseo la mantuvo oculta. Teseo debe vinoupríav a Piritoo por la posesión de Helena; añade el intento frustrado de raptar a la hija del rey de los molosos. ${ }^{58}$ Plutarco, en definitiva, detecta muchos de los rasgos que caracterizan la invención en la historia.

Menesteo es favorable a acoger a los Tindáridas frente a la actitud hostil de Teseo y, así, los Dioscuros fueron acogidos como 'Avake.${ }^{59} \mathrm{El}$ alquiler de esclavos se hace también en el Anákeion, el altar de los Dioscuros, al sudeste del ágora: ${ }^{60}$ los Anecdota Graeca $^{61}$ definen el Anákeion como santuario de los Dioscuros, donde los esclavos misthophoroûntes se ponen de pie, tal vez el tipo de esclavos que Nicias daba en alquiler para el trabajo en las minas. Es interesante constatar la expresión de Iseo, quien afirma que "hizo meter a Hermócrates en la cárcel alegando que era liberto suyo y no lo soltó hasta haber obtenido treinta dracmas de él", pero "en la cárcel" traduce el griego eis tò anankaîon..$^{62}$ Es posible que se trate de anakeîon, el mercado de Atenas, donde Hermón ha puesto a Hermócrates para venderlo o alquilarlo hasta obtener ese beneficio de treinta dracmas. La localización cercana al altar de los Dioscuros, donde se congregaban los caballeros en los momentos difíciles, como

54 Plu. Thes. 29.1-2.

55 Recogido en Ath. 13.357AB. Dice Ateneo (frg. 130 Rzach) que Hesíodo menciona otras uniones por las que violó el juramento de Ariadna, y antes de Helena había violado a Anaxo.

56 Recogido en Plu. Thes. 29.3.

57 Plu. Thes. 30.2-5.

58 Plu. Thes. 31.1-5.

59 Plu. Thes. 33.1-2.

60 Wycherley 1978, 97.

$61 \quad 1.212 .12$ (Bekker).

${ }^{62}$ Is. frg. 9 Roussel, perteneciente al discurso Contra Hermón. El fragmento está tomado de la Suda (s.u. anakaîon). 
ocurrió cuando la mutilación de los Hermas, ${ }^{63}$ justifica la descripción de Hesiquio, quien habla de un espacio rodeado por una línea y con el aspecto de un lugar para la equitación. Fue en el Anákeion donde se reunieron los hoplitas del Pireo, en armas, para parlamentar con los Cuatrocientos. ${ }^{64}$ Se trata, tal vez, de un lugar de integración de las clases más pudientes, frente a lugares más populares como el Teseo y el Leocorio, donde podían encontrar refugio incluso los esclavos. ${ }^{65}$ El Anákeion, dedicado a los Dioscuros, sería así un lugar de definición de los dominantes y de exclusión de los dependientes, como los lugares religiosos dedicados a la práctica atlética de tiempos de Solón. ${ }^{66}$ Las dimensiones debían de ser amplias por las funciones que se le atribuyen. La asamblea de la caballería se reunió en 415 a.C., ${ }^{67}$ pero Polieno sitúa aquí el desfile que Aristóteles pone en el Teseo, a propósito de Pisístrato ${ }^{68}$ quien reunió a todo el mundo con sus armas (metà hóplon), mientras que los epíkouroi dejan sus armas en el hierón de Aglauro. El recinto era al aire libre, según la descripción de Pausanias, ${ }^{69}$ y estaban representados en él los Dioscuros. Estaba situado entre el Teseo y el Aglaurio. Los thêtes y los esclavos encontraban protección en el Teseo, pero el Anákeion es el lugar donde los esclavos son vendidos o alquilados. Es, en definitiva, el lugar señero de las clases dominantes de una sociedad esclavista que se impone a través de la tiranía y, transformada, lucha contra la democracia de los thêtes. Situado muy cerca del Teseo, ${ }^{70}$ el Anákeion señala y define al sistema frente a la organización que hacía referencia a la libertad de los thêtes y a la emancipación de los esclavos. ${ }^{71}$

El mito que coloca a Menesteo contra Teseo tiene correspondencia en las referencias cultuales a la función de Teseo como liberador. En Helánico, Teseo envía a sus hijos a Eubea para protegerlos de Menesteo; en Plutarco, Menesteo se presenta como sucesor de Teseo..$^{72}$ Teseo, como símbolo de la protección de esclavos, encuentra correspondencia en Adriano cuando prohíbe matar esclavos, donde se encuentra la influencia del pensamiento estoico. ${ }^{73}$ Plutarco rechaza tradiciones sobre Etra y sobre Munico como hijo de Demofonte, así como la historia contada por Istro según la cual Héctor se había apoderado de Trecén y había raptado a Etra. ${ }^{74} \mathrm{La}$ confusa narración del final de Teseo en la Vida de Plutarco refleja las complejas relaciones del héroe con la tiranía y la democracia. Se trata de la concepción de la demokratía de la época antonina. ${ }^{75}$ La democracia de Teseo se define como resultado de un pacto entre los poderosos y de la victoria sobre los bárbaros.

Tras su muerte, los atenienses establecieron un culto como héroe en su honor, sobre todo por su aparición en Maratón, en un comportamiento similar a la búsqueda de sus huesos por orden de la Pitia y bajo la inspiración de Cimón, un cuerpo enorme

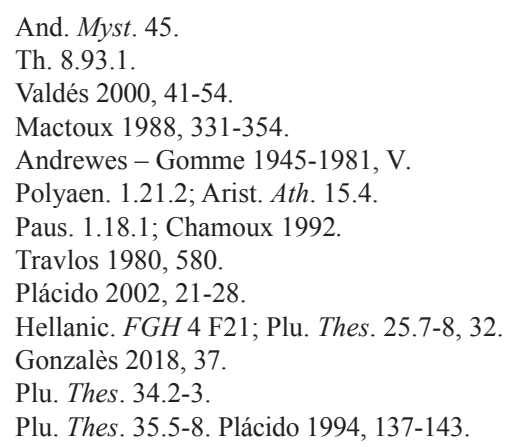


encontrado gracias a un águila; se inauguraron procesiones y sacrificios. ${ }^{76}$ Los huesos fueron enterrados en el centro, donde hay un gimnasio de época de Ptolomeo Filadelfo, asilo de esclavos y de todos los sometidos que temen a los poderosos

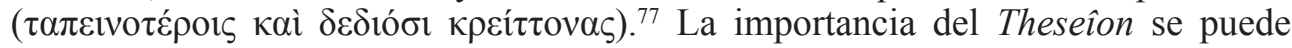
relacionar con la atención prestada a los esclavos en el escrito Sobre la superstición ${ }^{78}$

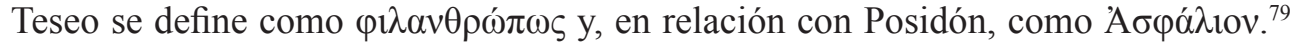
El octavo día de Pianepsión se celebraban los Theseîa, fundados por Cimón en 478, en relación con la expedición a Esciro, con procesión y competición atlética y generosa distribución de alimentos. Había una carrera de antorchas de jóvenes efebos y neanískoi en equipos, así como carreras en armas y a caballo. Así pues, al control del territorio y de los habitantes no griegos sometidos a servidumbre se suma el apoyo mítico en la figura de Teseo, con lo que la democracia mítica de Teseo se identifica con el imperialismo. Destacan igualmente las acciones contra los dólopes piratas, precedente de las hazañas de Cimón.

Cimón, como Teseo, se iba convirtiendo en bandera del programa de regreso a los tiempos anteriores a Salamina, a los tiempos de Maratón, victoria calificada de acto heroico ${ }^{80}$ identificable con las de los nobles del arcaísmo. Milcíades y Cimón pertenecen al dêmos de los Lacíadas, cuyo epónimo Lacio tenía su herôon cerca de la tumba de Fítalo, camino de Eleusis. ${ }^{81}$ Es el origen de las Oscoforias. La atención a las fiestas se confió a los Fitálidas, relacionados con Cimón, ${ }^{82}$ quien seguía teniendo autoridad después de muerto, base de la reconstrucción de la historia en línea cimoniana que pretendía restaurar la aristokratía de Clístenes. ${ }^{83}$ De todos modos, en las tradiciones destaca especialmente la presencia de Teseo, que se aparece en plena batalla, según la leyenda recogida por Plutarco; así se tiende un puente muy concreto entre el hoplita y el héroe, donde el aristócrata Cimón adopta el papel de intermediario. ${ }^{84}$ Las nuevas hazañas de éste al limpiar el Egeo se asimilan a las del héroe y él mismo se asimila a éste por sus acciones favorables y por su propia individualidad aristocrática. Después de las Guerras Médicas se introdujo el culto a Teseo, según Plutarco, gracias a que se trajeron sus huesos a través de la empresa de Cimón, lo que fue acompañado de brillantísimos sacrificios en Atenas. ${ }^{85}$ Las campañas de Cimón contra Eón y Esciro ${ }^{86}$ fueron los primeros pasos en la formación del Imperio ateniense, cuando su dirección se concebía como obra de un hombre a quien los beneficios le servían para actuar como evérgeta de sus conciudadanos y aumentar así su propio prestigio personal, heroico y aristocrático. ${ }^{87} \mathrm{La}$ acción se plantea como venganza por la muerte de Teseo. Pausanias compara la empresa a la preocupación por los huesos de Orestes por parte de los espartanos, lo que no deja de ser significativo del sentido que se daba entre los antiguos al hecho, representativo

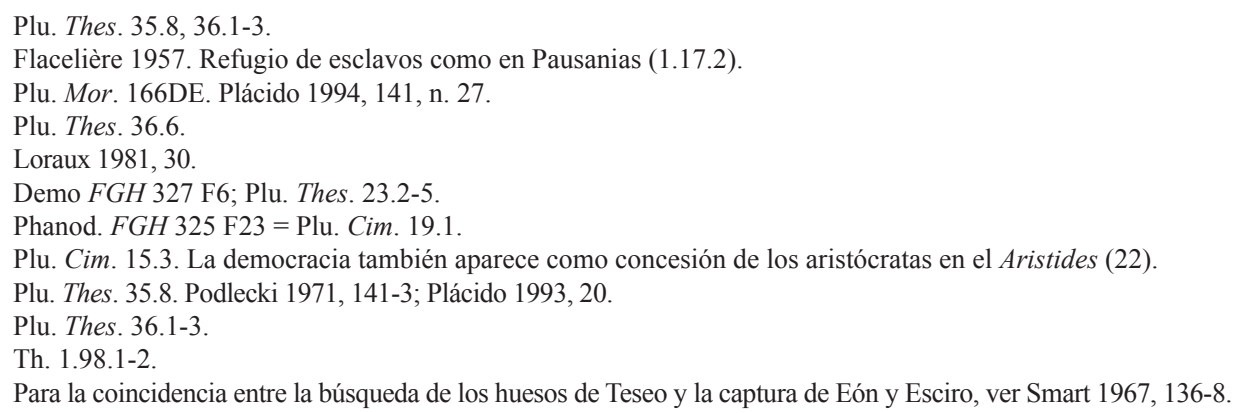


de la forma de actuar de la ciudad arcaica cuando buscaba su legitimidad en una vinculación directa con la época heroica. También resulta significativo que el propio Cimón recibiera un culto heroico en Citio. ${ }^{88}$

Como se ve, Plutarco recoge tradiciones sobre Teseo procedentes del siglo IV a.C., cuando los atenienses reelaboran su pasado para buscar bases sólidas que creen una fuerte esperanza de recomponer la situación de crisis en que se halla inmersa la ciudad desde la derrota en la Guerra del Peloponeso. Las bases se hallan sobre todo en los atidógrafos, que elaboran tradiciones asentadas en el arcaísmo para adaptarlas a los intereses de la época. El argumento central es el pasado glorioso de Atenas, donde resulta clave el papel de Teseo.

\section{La Atidografía}

Filócoro escribió libros de Atthis que abarcan las acciones, los reyes y los arcontes

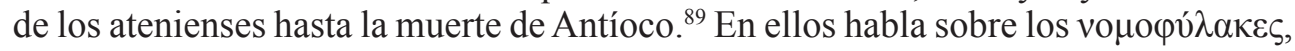
guardianes de las leyes, como los que obligaban a las magistraturas a usar las leyes: establecidos durante las reformas de Efialtes, todos los estudiosos insisten en

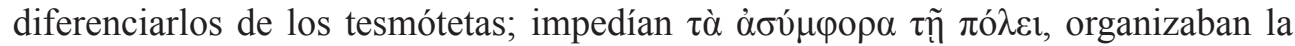

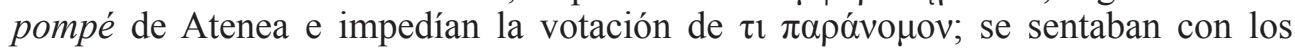
proedros en la asamblea y la boulé frente a los arcontes cuando Efialtes dejó al

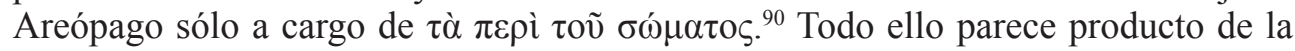
ideología del siglo IV a.C. sobre los primitivos poderes del Areópago, cuando se trata de borrar la fuerza en que se basa el funcionamiento de la Asamblea en la época en que se situaba por encima de las leyes. ${ }^{91}$ Filócoro se fija en los antecedentes de las reformas de Efialtes y es el único que parece remontar la institución a épocas anteriores, que ya estaría privada de funciones desde 460 por Efialtes. ${ }^{92}$ Se trata, por tanto, de una relectura de la historia para justificar las actuales limitaciones de la democracia.

En la Política, ${ }^{93}$ Aristóteles declara que la institución era propia de la oligarquía y, más tarde, igual que Filócoro, menciona a los "cincuenta y uno" de entre los hombres más ilustres en relación con el Areópago. ${ }^{94}$ Según Filócoro, el Areópago estaba formado por los más ilustres ( $\tau \tilde{\omega} v \pi \varepsilon \rho 1 \varphi \alpha v \varepsilon \sigma \tau \varepsilon \dot{\varepsilon} \rho \omega v) .{ }^{95} \mathrm{La}$ ampliación sería de 594, y no tendría función política, sólo como jueces, para juzgar toda clase de faltas y transgresiones. ${ }^{96}$ Entre los areopagitas estaban los arcontes. Sólo forman

88 Paus. 3.3.7; Plu. Cim. 19.5 .

89 Philoch. FGH 328 T1 (= Suda, s. v.). Proclo lo cita entre los intérpretes $\tau \tilde{\omega} v \pi \alpha \tau \rho i ́ \omega v(T 2=$ Procl. ad Hes.Op. $810)$.

90 Philoch. FGH 328 F64a, 64ba, 64b $\beta$. Ver O’Sullivan 2001, 51-62, que acepta la versión de que fueron creados por Demetrio de Falero.

91 Gallego 2018, 157-159.

92 Aunque ya la Constitución de los atenienses (Arist. Ath. 3.6) la remonta a Dracón.

93 Arist. Pol. $4 \cdot 14 \cdot 14=1298$ b 26-32.

94 Arist. Pol. 6.8.24 = 1323a 6-10; Philoch. 328 F20b. Valdés 2012, 149.

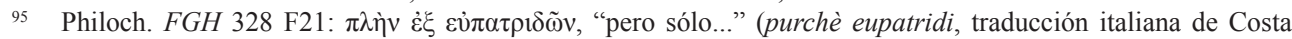

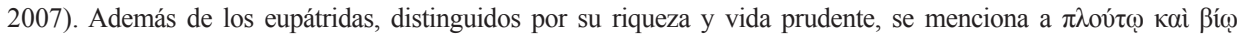

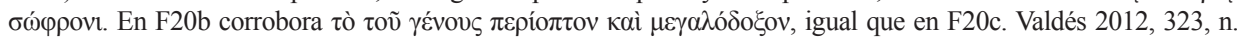
1440 .

96 Costa 2007. Philoch. FGH 328 F20a. Valdés 2012, 223, n. 864. 
parte del Areópago los primeros por el génos, en riqueza, o por vida honesta (chrestôi). ${ }^{97}$

Filócoro abunda en el origen del nombre y en el hecho de que juzguen casi todos los delitos. ${ }^{98}$ Los atidógrafos sostienen que el Areópago tenía poderes amplios en el Arcaísmo, ${ }^{99}$ en correspondencia con la Constitución de los atenienses y con Isócrates, ${ }^{100}$ en la línea característica de la Restauración, cuando se trata de recuperar una democracia no radical y como ocurre en toda la historia después de una situación de shock. ${ }^{101}$ Según Filócoro, ${ }^{102}$ la muerte de Halirrotio por Ares, que había violado a Alcipe, hija de Ares y Agraulo, dio lugar al tribunal de crímenes de sangre. Helánico se refiere al juicio de Orestes en el Areópago después del juicio de Ares y Posidón por Halirrotio, aunque varían los años que separan los actos. ${ }^{103}$ En el escolio a Eurípides ${ }^{104}$ los areopagitas solían citar a los derrochadores y los que apenas podían ganarse la vida. ${ }^{105}$ Según Helánico, ${ }^{106}$ en el Areópago, dikastérion ateniense, Ares juzga sobre los asesinatos, porque clavó la lanza en el juicio contra Posidón a propósito del asesinato de Halirrotio; con ello se anticiparía a la versión recogida por Esquilo sobre la fundación del Areópago, dado que existiría desde antes. ${ }^{107}$ Helánico parece apoyarse en tradiciones áticas antiguas, de inicios del siglo V a.C., así como en autores como Damastes. ${ }^{108}$ Las tradiciones, por tanto, pueden crearse para asentar las reformas: ${ }^{109}$ las de Efialtes primero y las de las leyes tras la derrota contra Esparta configuraron la contradictoria historia del Areópago.

Helánico aborda el período desde Ogigo hasta la primera Olimpíada. ${ }^{110}$ Según Julio Africano, ${ }^{111}$ trata de la cronografía del Ática desde Ogigo, considerado autóctono entre ellos, nacido en Ática durante el reino de Foroneo, como cuenta Acusilao: éste se refiere a un cataclismo después de Ogigo hasta Cécrope, que sería la época $\dot{\alpha} \beta \alpha \sigma i \lambda \varepsilon v \tau o \varsigma .{ }^{112}$ Ferécides dice que los atenienses son autóctonos. ${ }^{113}$ La tradición difundida en Atenas por Ferécides en el siglo V a.C. y recogida por Estrabón y Pausanias, ${ }^{114}$ atribuye el protagonismo de la colonización de los jonios a Atenas y a Neleo, hijo del rey Codro, lo que parece tener cierto apoyo documental, al menos en el sentido de que, en un período de inestabilidad de las poblaciones, entre Atenas y Asia Menor se produjo la identificación y definición de la etnia de los jonios, con participantes de diversos orígenes. Helánico se refiere a Eritras en Jonia como fundación de Neleo, hijo de Codro; éste, el primer rey mítico de Atenas, según una

\footnotetext{
Philoch. FGH 328 F20b.

Philoch. F4; cf. Androt. F3.

Costa 2007.

Arist. Ath. 3.6; Isoc. 7.37-46.

Klein 2010.

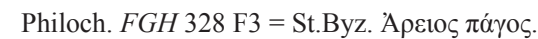

Hellanic. FGH 4 F22a.

Or. 1648 = Philoch. FGH 328 F196.

Valdés 2012, 223, n. 864.

$\mathrm{F} 38=$ FGH 323a F1.

Mazzarino 1974, I 96.

Mazzarino 1974, I 205.

Hobsbawn 1983, 8.

F47 $E G M=F G H 323$ a F10.

11 En Eusebio (Praeparatio Evangelica 10.10.7-8, 14).

12 Acus. FGH 2 F23.

113 Pherecyd. FGH 3 T2 = EGM 2.

114 Str. 14.1.3; Paus. 7.2.1.
} 
versión, aparece unido a otros héroes, como Teseo y Áyax, en algunas representaciones. ${ }^{115}$ Es posible que tuvieran un santuario en el área del Iliso, ${ }^{116}$ junto con Neleo y Basile.

Ferécides trata de la genealogía de Milcíades, que remonta a Áyax, en lo que coincide con Helánico. ${ }^{117}$ Codro se encontraba ya integrado en la época de Paníasis, de Ferécides y de la base de Maratón, cuando se exaltaban las hazañas de las Guerras Médicas, con lo que se marca una coincidencia entre la exaltación del pasado hoplítico y el pasado mítico heroico, que reúne en una misma imagen todos los elementos del pasado, por muy heterogéneo que pudiera ser su origen. La zona del Iliso fue privilegiada en época arcaica y, especialmente, en época pisistrátida. Allí se inició el templo de Zeus Olímpico. En el témenos de Codro habría íkria, lugar que puede interpretarse como recinto para contemplar prácticas rituales, sin duda relacionadas con el héroe mítico, válidas para hacer que la comunidad se sintiera solidaria con su imagen pasada, creadora también de una mentalidad que favorecía la aceptación de la desigualdad, incluso en época democrática. Una inscripción ${ }^{118}$ confirma el culto en una época $-418 / 7$ a.C., en plena guerra- en que hacía falta la consolidación de tal solidaridad, en un momento de paz precaria y renacimiento de la agresividad, encauzada así a través de la realeza, de la basileía con que se relaciona íntimamente el culto.

Según Helánico, ${ }^{119}$ Codro desciende de Deucalión y Pirra, pero de ésta y Zeus nace Helén, antepasado de Tiro que tuvo a Neleo de Posidón, y de ahí Melanto, exiliado de Mesenia, que combatió con Jantio y reinó en Atenas tras vencerlo con engaño (á $\left.\alpha_{\alpha} \tau \eta\right)$, de donde proviene el nombre de las Apaturias. Luego recibe la realeza Codro, que muere por Atenas en guerra con los dorios. Su ejemplo lo pondrá como modelo Licurgo. ${ }^{120} \mathrm{Su}$ hijo Neleo fue fundador de la dodecápolis jonia. ${ }^{121}$ Paníasis escribió sobre Heracles, pero también sobre Jonia, ${ }^{122}$ y trata de Codro y la colonización, atribuyendo el protagonismo jonio a los atenienses a propósito de Colofón. ${ }^{123}$ Helánico, que se remonta a Codro, hijo de Deucalión, por lo que se dice

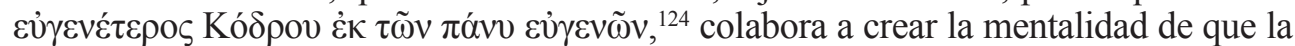
superioridad ateniense justificadora de su dominio se apoya en el pasado mítico que enaltece a la ciudad, pero también a su aristocracia.

Con las Guerras Médicas se define la etnicidad griega frente a la bárbara y se configura el panhelenismo, pero encabezado por los atenienses, por lo que al mismo tiempo se define la superioridad ateniense entre los griegos. ${ }^{125}$ Contribuye a la definición de la etnia griega y a destacar el papel ateniense a través del papel de Teseo. También la Amazonomaquia, que es además marca de barbarie de las mujeres en el androcentrismo ateniense. Al mismo tiempo, Teseo potenciaba el papel de la aristocracia en la creación de la democracia, lo que favorece su

\footnotetext{
115 Hellanic. FGH 4 F11. Beazley 1963, 1268, 1. Ver Robertson 1988, 225-230.

116 Wycherley 1978, 168-169.

117 Pherecyd. FGH 3 F2 = Marcellin. Vit.Thuc. 3; Hellanic. FGH 4 F22.

$118 I G^{3} 84=S I G^{3} 93$.

$119 \mathrm{~F} 125 \mathrm{EGM}=$ FGH 323a F23, del escolio al Banquete de Platón (208D).

120 Lycurg. Leoc. 83.

121 Ver también FGH 323a F11; Hdt. 1.174, 5.65; Paus. 2.18.8-9, 7.1-2; Str. 9.1.7, 14.1.3. Valdés 2012, 38.

122 Panyas. $P E G 1 \mathrm{~T} 1 \mathrm{~B}=$ Suidas.

123 Mazzarino 1974, I 119

124 FGH 323 F23.

125 Cohen (2001) insiste en el valor representativo del frontón de Olimpia.
} 
adaptación de la demokratía de los Antoninos en Plutarco. Por otra parte, la iconografía con vestimentas tracias o persas revelaría la concepción de la etnia ateniense como integradora del Imperio. ${ }^{126}$ La helenidad se define asimismo como vinculada a la polis "libre" frente al despotismo de los imperios, definidos como tributarios por Heródoto y otros, ${ }^{127}$ con los que además se identifican las tiranías, sobre todo en los acontecimientos previos a la revuelta jónica. De ese modo, la tiranía, que había colaborado a la consolidación de la polis, pasa a identificarse con el orientalismo. Todo se relaciona con la invención teórica de la superioridad de Atenas. Los persas en cambio, dentro de la sumisión tributaria, respetan la autonomía de las ciudades, como Éfeso e incluso Mileto después de la sumisión. Con las Guerras Médicas, la identidad helénica se apoya en Delfos, administrado por la Anfictionía, y en Olimpia, en la que el santuario extraurbano de Elis sufre la competencia de Esparta. ${ }^{128}$

Al referirse a Helánico, Harpocración dice que también Demóstenes llama a los atenienses autóctonos, ${ }^{129}$ pero también a los arcadios, los eginetas y los tebanos. Sobre la autoctonía de los atenienses, resulta especialmente detallado el Jon de Eurípides. Tucídides - por boca de Pericles- se refiere a este mito para afirmar que Atenas estaba libre de invasiones. ${ }^{130}$ Jon aparece también en la Constitución de los atenienses como llamado para solucionar las guerras y a sus hijos se refieren los nombres de las tribus. ${ }^{131}$ La leyenda es más complicada que la expuesta por Aristóteles, como se ve en Heródoto, Tucídides, Estrabón o Pausanias; ${ }^{132}$ este último cuenta que los jonios expulsaron a los esmirneos y luego los admitieron en el Panjonio; fue entonces cuando adoptaron el nombre de atenienses. La historia de Jon es la que justifica el patrocinio de Apolo. ${ }^{133}$

Clidemo es considerado el primer historiador de Atenas, identificado normalmente con el Clitodemo de Pausanias. ${ }^{134}$ Plutarco distingue a Clidemo y otros como Filócoro de Jenofonte, ${ }^{135}$ que escribió sobre sí mismo, mientras que los otros habrían escrito sobre acciones ajenas. Según Plutarco, Clidemo cuenta algo peculiar sobre la historia de Minos: que había una norma de todos los griegos que impedía zarpar una nave con más de cinco tripulantes; ${ }^{136}$ Dédalo huyó a Atenas y Minos lo persiguió contra la norma. Dice Clidemo en Atthis que se eligieron parásitoi en honor de Heracles, y habla también de ofrendas a los muertos. ${ }^{137}$ Hipérides afirma que "se reunían en la

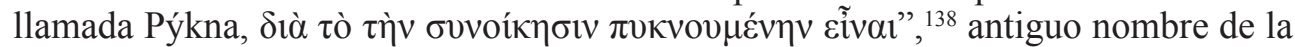
Asamblea. Clidemo afirma que Clístenes dividió las tribus en cincuenta naucrarías y cien symmoriai, ${ }^{139}$ por tanto le atribuye a las naucrarías funciones similares a las de

126 Cohen 2001, 261.

127 Wiesehöfer 2009.

128 X. $H G$ 3.2.21-31. Nielsen 2007, 29.

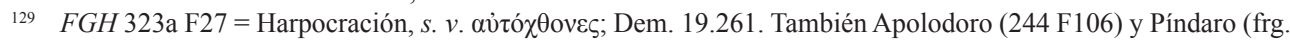
$253 \mathrm{Schr}$. 268 Bowra; Erictonio hijo de Hefesto, nacido de la tierra).

130 Th. 2.36.1; cf. 1.2.5. Saxonhouse 1986, 257.

131 Arist. Ath. 3.2, 8.3.

132 Hdt. 8.44.2; Th. 2.15; Str. 1.31; Paus. 7.5.1.

133 Arist. frg. 381 Rose. Sobre las tribus, frg. 385 Rose.

134 Clidem. FGH 323; Paus. 10.15.5 = T1.

135 Clidem. T3; Plu. De gloria Atheniensium $1=$ Mor. 345E.

136 Thes. 18.9. El texto es muy corrupto, ver Flacelière 1957.

$137 \mathrm{~F} 11=$ Athen. 6.235A; 9.410. Los manuscritos oscilan entre Clidemo o Anticlides.

138 FGH 323 F7 (= frg 182 B1-J), recogido en Harpocración s.u. Пvкví.

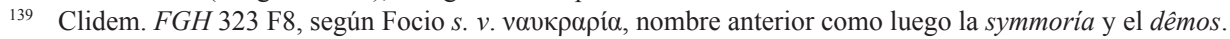


las symmoríai posteriores. ${ }^{140}$ También afirma que los atenienses se llamaban jonios, ${ }^{141}$

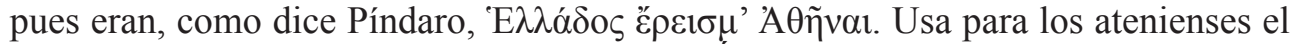
nombre de 'Ióoves, de Jon, hijo de Juto, hijo de Éolo, hijo de Helén, de la Tetrápolis. ${ }^{142}$

Clidemo se refiere a la Batalla con las Amazonas: ${ }^{143}$ el ala izquierda se extendía hasta el actual Amazonio y el ala derecha hasta Crisa cerca de la Pnix; se conmemora en las Boedromias. Menciona así varios lugares de Atenas: Pnix, Crisa, Museo, las puertas del héroe Calcodonte que van a El Pireo, las Euménides, Paladio, Ardeto, Liceo; también habla de la intervención de Hipólita, del santuario de Gea Olimpia, el Amazonio y el Teseo llamado Horcomosio. Jon, hijo de Juto y Creúsa, procede de Tesalia, y se dedica a la fundación de la Tetrápolis de Maratón. ${ }^{144}$ Refleja también las relaciones con la costa oriental del Ática, trata sobre el témenos de $\mathrm{Teseo}^{145} \mathrm{y}$ la reunión del dêmos.

Androción se define como demagogo discípulo de Isócrates, que recibió la corona de oro en 357 a.C. ${ }^{146}$ Hace una defensa de la democracia como la de Solón y propone su recuperación junto con un rechazo del imperio del mar, así como la guerra para controlar a los bárbaros, con precedentes en Temistocles y Teseo. Según Plutarco,

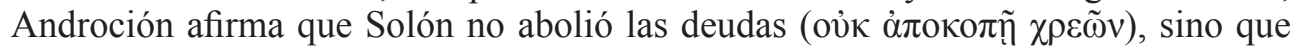

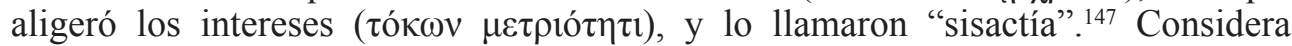
también que se trata de una de las dulcificaciones del lenguaje a que son aficionados los atenienses: ${ }^{148}$ Androción no quiere atribuir a Solón una medida revolucionaria como las que en su época causaban revuelo y estaban en el eje de las luchas sociales del siglo IV a.C.; puede ser un elemento importante del espíritu de la Atidografía y del ambiente general de la época, más que debido a una postura política concreta de Androción ${ }^{149}$ y menos aún como propaganda política de su parte. Se integra en la tradición que trataba a Solón como fundador de la democracia. ${ }^{150}$ En cambio, Filócoro se refiere a las deudas públicas y privadas en la época presoloniana ${ }^{151}$ y a la sisactía entendida como $\chi \rho \varepsilon \omega \kappa о \pi i ́ \alpha$ de las deudas públicas y privadas, pues era costumbre que los pobres deudores trabajaran con el cuerpo para liberarse de la carga,

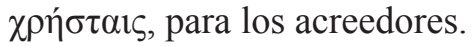

La relación de Teseo con la democracia también se encuentra en el grupo de Democracia coronada por el Dêmos en Pausanias. ${ }^{152}$ Hay representaciones también en la estoa de Zeus Eleuterio, con los Doce Dioses. Allí mismo está la estatua de Adriano con la de Conón, que restaura la liberación de Atenas, relacionada topográficamente con la de Zeus Eleuterio. ${ }^{153}$ Teseo fue el que instauró la igualdad

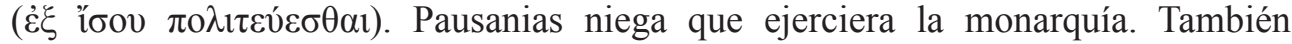
aparecen las representaciones de Demokratía y Dêmos con Teseo como instaurador

\footnotetext{
140 Valdés 2012, 276, n. 1124.

141 Clidem. FGH 323 F13, en escolio a Calímaco (pap. Berol 11521, 29 Pf).

142 Valdés 2012, 187, n. 693.

143 Clidem. FGH 323 F18, que recoge Plu. Thes. 27.2-7.

144 Clidem. FGH 323 F19 = Paus. 7.1.1-4. Valdés 2012, 183, n. 667; 187, n. 693.

145 Clidem. FGH 323 F177. Valdés 2012, 170, n. 613.

146 FGH $324 \mathrm{~T} 1, \mathrm{~T} 7$ (=IG XII $7 \mathrm{n}^{\circ} 5=$ Syll. $\left.^{2} 193\right)$.

147 Plu. Sol. $15.3=$ FGH 324 F34.

148 Plu. Sol. 15.2.

149 Harding 1994. Interpretaciones variadas en Harding 1974.

150 Arist. Ath. 9.1; Isoc. 7.17.

151 Philoch. FGH 328 F114; Valdés 2012, 304, n. 1305.

152 Paus. 1.3.2-4. Dowden 1992, 88.

153 Beschi-Musti 1990.
} 
de la democracia, para conseguir la unión de reino y democracia. Atenas aparece así en su tradición tiránica y democrática, entre Solón y Pericles. Adriano se manifiesta en la implantación de su poder como respetuoso con la tradición democrática de Teseo, que hizo de Atenas un ásylon, y dotó a la ciudad de fama como ciudad de accueil. Tal vez la coraza con Rómulo y Remo sostenidos por la loba refleja su idea de los privilegios y las servidumbres de Atenas, como se reflejan en tragedias de Eurípides como Heraclidas, en la tradición de Ferécides. ${ }^{154}$

Así se muestra en la intervención de Augusto-Agripa en Dion Casio: "Atenas es nuestra", expresión del neoclasicismo augústeo. Roma practica la implantación de edificios simbólicos en lugares abiertos, en grandes espacios, para darle un aspecto grecorromano, con la presencia de Ares en el ágora. La efebía llegó a ser una forma de integración de la juventud y vehículo del culto imperial. Marco Aurelio percibirá la crisis y recurre a la Fortuna como solución; Adriano pretendía todavía la expansión del evergetismo. Las fiestas de Teseo eran ocasión para la distribución de alimentos, ${ }^{155}$ con un nuevo relieve del Theseîon como lugar de acogida. En esta época la protección se dirige a los humiliores.

Androción cuenta la historia de Edipo en Colono y la acogida por Teseo. ${ }^{156} \mathrm{Se}$ señalan aquí Atidografía y tragedia. Filócoro se refiere al Colono agoreo donde van los llamados $\mu 1 \sigma \theta \omega \tau$ ov̀ $\varsigma$ Ko $\lambda \omega v \varepsilon ́ \tau \alpha \varsigma,{ }^{157}$ cerca del ágora donde el templo de Hefesto y el de Eurisaces, distinto del Colono junto al templo de Posidón, el Colono de los caballos o de los caballeros. Cerca se encontraban los herôa de Teseo y Piritoo y de Edipo y Adrasto. ${ }^{158}$ Androción expone la genealogía de Eumolpo, ${ }^{159}$ el que luchó contra Erecteo, e incluye a Museo. Erecteo y su lucha contra Eumolpo sirven también de modelo a Licurgo, quien cita también los versos del Erecteo de Eurípides, ${ }^{160}$ autor que igualmente recoge tradiciones sobre la historia patria de Atenas. Apolodoro cuenta la historia, incluido el oráculo por el que tenía que sacrificar a su hija para alcanzar la victoria. ${ }^{161}$ Plutarco rescata otros versos atribuidos al Erecteo de Eurípides, que alaba a Atenas y los habitantes autóctonos. ${ }^{162}$

Otros aspectos relacionados se muestran en Platón y en su descripción del Imperio de los Atlántidas. Se ofrece una imagen del pasado en que se contrasta la época preimperial idealizada con la época del Imperio que causó la decadencia por causa del dominio del dêmos. En Critias se elabora una realidad alternativa que pretende demostrar cuáles son las condiciones de realización de la utopía de la República. Critias quiere demostrar que el estado ideal es más realizable que el proyecto democrático imperialista y tiene su modelo en la Atenas primitiva. La Atenas primitiva derrota a los atlantes como señores de África, pero será destruida por una catástrofe natural. ${ }^{163}$

\footnotetext{
154 Pherecyd. FGH 3 F 84 = Ant.Lib. 33 (refugio de los Heraclidas en Atenas, en época de Demofonte). Plácido 2013.

155 Parke 1977, 81.

156 FGH 324 F62.

157 Philoch. FGH 328 F26.

158 Paus. 1.30.4. Costa 2007.

159 FGH 324 F70.

160 Lycurg. Leoc. 98, 100.

161 Apollod. 3.15.4.

162 Sobre el exilio 13 = Mor. 604DE (= Nauck 360.7-10; Kann 981). Volpe 2017, 113.

163 Pl. Criti. 110-112; Ti. 25A.
} 


\section{La imagen del pasado en el siglo IV a.C.}

En la época democrática se desarrolla la idea de un pasado glorioso identificado con Maratón, del que un ejemplo notable se halla en el discurso fúnebre, estudiado de modo destacado por Nicole Loraux. ${ }^{164}$ Ejemplos variados se ofrecen también en Lisias, Demóstenes, Hiperides y, como parodia, en el discurso de Aspasia en Menéxeno de Platón. ${ }^{165}$ El mito de los orígenes aparece asimismo en Político. ${ }^{166}$ Aquí no hacen falta mujeres y en el de Aspasia no hacen falta hombres. El tema de la autoctonía domina el prólogo de Hermes y se enlaza con la violencia en la fundación de la ciudad, con la violación de Creúsa. Se centra en la ciudad de Atenas. La obra establece la función del mito para comprender la ciudad, pero también marca las críticas a las limitaciones que ofrece la vida ciudadana de Atenas. ${ }^{167}$ El discurso de Licurgo, Contra Leócrates, se considera el paradigma de la política de recuperación del glorioso pasado ateniense en la época de desánimo posterior a Queronea, coincidente con algunas inscripciones, como la que propone reforzar el culto de Atenea Nike con alusión a la victoria de Platea a pesar del momento subsiguiente a la derrota.

Isócrates se propone hacer justicia a los griegos de las Guerras Médicas y admite la necesidad de inventar. ${ }^{168}$ Así pues, el uso del pasado sirve como antídoto contra la realidad. ${ }^{169}$ Isócrates, más que a Heródoto, menciona a poetas y sofistas como mayores exponentes de la memoria. La poesía se recitaba en simposios y configuraba el pasado para las familias aristocráticas, ${ }^{170}$ aunque podían ser críticos, como en el caso de Agamenón y de algunas referencias a Aquiles. En los festivales extendían la publicidad al resto del público hasta que se dedicaron a hacer el pasado de las ciudades. La invención del pasado no es puramente lineal.

En la tragedia se pasa directamente a la ciudad y se asumen las contradicciones del pasado. ${ }^{171}$ Isócrates se inserta en la tradición de conmemorar el pasado. Las Guerras Médicas también fueron utilizadas por Alejandro para exaltar la unidad griega frente a los persas y frente a Tebas, ${ }^{172}$ de esa forma controlaba la memoria histórica de los griegos y la idea de eleuthería ${ }^{173}$ En Areopagítico, del año 355 a.C., pretende dar una imagen estática del culto ancestral y dice que se conservan las

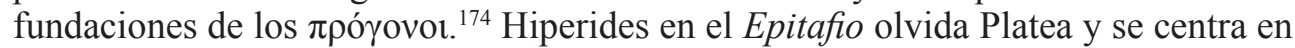
Tebas, porque ésta es ahora la víctima de Alejandro. ${ }^{175}$ Ahora la Guerra Helénica es contra los macedonios. En esa misma línea se mueve Platón en Critias, según Morgan. ${ }^{176}$

\footnotetext{
64 Loraux 1973.

165 P1. Mx. 237B-C.

166 Saxonhouse 1986, 258.

167 Saxonhouse 1986, 273.

168 Isoc. 4.82; 12.172-174. Grethlein 2014, 242.

169 Grethlein 2014, 245.

170 Grethlein 2014, 242.

171 Grethlein 2014, 242.

172 Wallace 2011, 148

173 Wallace 2011, 151.

174 Isoc. 7.29-30. Garland 1992, 46.

175 Wallace 2011, 158.

176 Morgan 1998.
} 


\section{Plutarco: época imperial}

En el Imperio romano, la idea de la estabilidad como modelo oculta importantes cambios, incluso en la época de Adriano. ${ }^{177}$ Pero lo que se muestra por el contrario es una gran eficacia en los planteamientos simbólicos para dar una imagen convincente de la estabilidad de la ecúmene. ${ }^{178}$ Ello puede percibirse en varios aspectos de su comportamiento, pero, de un modo muy notable, en todos los relacionados con Grecia y, en concreto, con Atenas. La cultura griega y el simbolismo representado por la ciudad de Atenas resultaron clave en la elaboración del imaginario imperial de la época de Adriano.

Adriano se presenta como actualizador de la Atenas de Solón en la Ley Olearia. ${ }^{179}$ Es importante la dirección que toma la política hacia la recuperación de la timocracia. ${ }^{180}$ Las condiciones históricas favorecían la promoción de libertos ricos. ${ }^{181}$ Se resalta en el texto de la inscripción el papel de la ekklesía como organismo de reclamación para el cumplimiento de la ley, ${ }^{182}$ con un protagonismo superior al de otros textos de la época. La referencia se completa con la de las líneas 56-57 al voto del dêmos. El texto se expuso en la puerta de Atenea Arquegetis, en el mercado romano, lugar de prácticas evergéticas, como las inauguradas por Domiciano y seguidas por Trajano en los mercados romanos que reciben el nombre de éste. ${ }^{183}$

Adriano presenta un programa de demokratía, como la del buen emperador de Elio Aristides. Éste imaginaba que los atenienses podían considerarse por todos los humanos como los $\tau \rho \circ \varphi \varepsilon ́ \alpha \varsigma:$ todo lo propio del hombre, lo que está en las ciencias

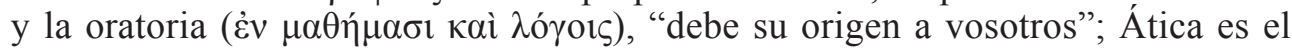
centro de Grecia como Grecia es el centro de la tierra; la ciudad se relaciona con Heracles, como protector de todos los hombres, cuyos hijos protegió, a través de su amistad con Teseo, son los benefactores de toda la tierra en una distribución

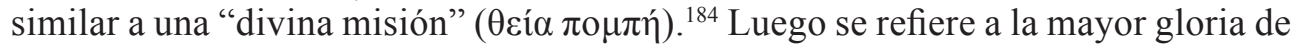
los atenienses alcanzada en la lucha contra los persas sin ayuda de nadie, lo que significó la libertad para todos los griegos: eran los únicos que consideraban su tierra como ajena y la ajena como propia, pues eran los guardianes de toda Grecia, pero no por la fuerza, sino como patronos $(\pi \varepsilon \rho ı$ ó $\lambda$ ovs); todas las ciudades y los pueblos se inclinan hacia el modo de vida y el habla de los atenienses, considerada como el habla de toda la raza humana, pues la ecúmene ha llegado a tener la misma lengua. ${ }^{185}$ Para el orador, el protagonismo de las relaciones con los dioses en Ática lo tiene Teseo y las Panateneas son los juegos más ilustres de Grecia. Muchas razones habría para dar a Atenas la supremacía, pues con ella todos pueden sentirse orgullosos. ${ }^{186}$

177 Plácido 2004, 19.

178 Plácido 2004, 33.

179 Plácido 1992, 171, ver n. 2. $I G \mathrm{II}^{2}$ 1100. En la nota 1 se halla una referencia sintética a la bibliografía anterior.

180 Levick 2000, 628.

181 Luciano satiriza el proceso cuando se refiere a los mortales que pretenden integrarse en la Asamblea de los

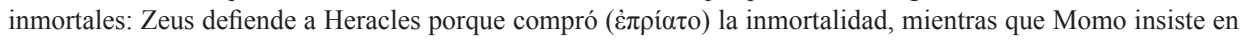
la entrada de bastardos y extranjeros (Luc. Deor.Con. 3.6.13).

182 Plácido 1992, 172.

183 Wycherley 1978, 102.

184 Aristid. Or. 1.1 (=150D), 1.2, 1.16 (=159D), 1.35 (=167D), 1.36-37 (=167D).

185 Aristid. Or. 1.110 (=203-204D), 1.205 (=248D), 1.322 (=294D), 1.324, 1.325.

186 Aristid. Or. 1.360 (=307D), 1.362 (=308D), 1.403 (=320D). 
Las acciones de Adriano parecen integrarse en esa misma concepción de la hegemonía ateniense: Adriano sería sucesor de $\mathrm{Teseo}^{187}$ como fundador de una democracia paternalista, similar a la que había conseguido Pericles a través de la persuasión. ${ }^{188}$ Recoge así la tradición del Anónimo de Jámblico, que opone la circulación de la riqueza a la tiranía. Atenas es también en esa época asilo de excluidos: Adriano reconstruye para ello el templo de Teseo. ${ }^{189}$ Del mismo modo, éste es lugar de refugio de esclavos, papel que se remonta al ágora vieja. Ahora se produce un nuevo impulso a la idealización de la Atenas de Teseo, considerado como fundador de la democracia, la cual resulta así enfocada como concesión evergética ${ }^{190}$ y como proyección de la organización doméstica, del ổkos. Adriano elige el Iliso como escenario del culto imperial, ${ }^{191}$ zona delimitada ahora por la Puerta de Teseo, arco simbólico de la separación entre la Atenas clásica y la nueva Atenas de Adriano, en la que sin embargo se incluye el espacio sacro fundacional a que se refiere Tucídides, hacia la zona en que se sitúa el ágora vieja. De hecho, era ésta una de las puertas de la ciudad clásica. Allí terminó Adriano el templo de Zeus Olímpico, iniciado por el tirano Pisístrato y donde había intervenido Antíoco IV, siguiendo en cierta medida la tradición de los autócratas protectores de los oprimidos.

Se manifiesta igualmente la supremacía de Atenas en el Panhelenio y al mismo tiempo la supremacía del emperador. Se destaca la importancia topográfica de la puerta de Adriano. Crece la difusión de formas soteriológicas en el respeto al helenismo, ${ }^{192}$ cuando se consideró que la salvación de la tradición de la ciudad estado estaba en el poder personal benefactor, poder que se concreta en el respeto de Adriano al espacio democrático de Teseo. ${ }^{193}$ La reforma de las leyes, con un consejo de quinientos sobre el modelo de Clístenes, con Annio Pitodoro como nomothétes, se acompaña con la introducción de Adriano en la lista de héroes epónimos. ${ }^{194} \mathrm{La}$ dedicación del templo de Zeus fue acompañada de un ara dedicada a sí mismo, ${ }^{195}$ un culto que se difunde entre los griegos por la voluntad del mismo Adriano (volente Hadriano). ${ }^{196}$ Fue arconte en Atenas en 112 d.C., antes de acceder al imperio, y llamó Hadrianópolis a esta parte de la ciudad. ${ }^{197}$ En beneficio de la ciudad oficialmente y de algunos atenienses en particular, construyó un gimnasio ${ }^{198}$ que a veces se relaciona con la Biblioteca, aunque también con el templo mencionado por Pausanias, hipotéticamente considerado de Heracles llamado Cinosarges, con altares de Heracles y Hebe, aunque no menciona el gimnasio en que enseñó Antístenes. ${ }^{199}$ La finalidad

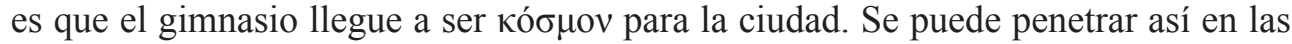
consideraciones sobre el carácter inevitable de la decadencia, frente a la comprensión de los apoyos en que se sustentaba la estabilidad de la ecúmene, más ideológicos que

\footnotetext{
187 Plácido 1992, 173.

188 Plu. Mor. 802C.

189 Plu. Thes. 36.4.

190 Ver Plácido 1995b, 383-389.

191 La zona sacra tradicional, según Tucídides (1.15.4). Plácido 1995a, 249.

192 Plácido 1995a, 251

193 Plácido 1997, 177-188

194 Birley 2003 (=1997), 231.

195 SHA Hadrianus 13.6.

196 SHA Hadrianus 14.7.

197 SHA Hadrianus 19.1 y 20.4, respectivamente.

198 Martín 1982, nº 45.

199 Paus. 1.19.3. Chamoux, 1992, ad loc.
} 
estructurales. Se observa de este modo un gran despliegue de los medios, representados por los intelectuales orgánicos. ${ }^{200}$

En la época de Adriano, el Iliso funcionó como escenario del culto imperial, ${ }^{201}$ lo que significa la supremacía de Atenas en el Panhelenio y la supremacía del emperador. De ahí la importancia de la puerta de Adriano, junto con la difusión de formas soteriológicas en el respeto al helenismo. ${ }^{202}$ Se muestra así el respeto de Adriano al espacio democrático de Teseo, ${ }^{203}$ por lo que Atenas aparece sostenida por la loba: no domina, sino que subsiste gracias a Roma. ${ }^{204}$

En todo el proceso de intervención adquiere una importancia especial la localización de la puerta de Adriano, delimitando el espacio del Iliso. La fuerza de la intervención no impidió que se señalara el respeto de Adriano al espacio democrático definido como la Atenas de Teseo. El arco se define en la topografía de la ciudad como vía de comunicación del espacio apropiado por el emperador con el Theseîon como lugar de asilo. Así se destaca de nuevo la figura de Teseo como exiliado, tal como se define en la Vida de Plutarco. Sobre esa tradición mítica se basaba la relación del santuario con la protección de los esclavos. El régimen de Adriano se define así como un régimen democrático "evergético", como el sistema que se impuso en Atenas después de las Guerras Médicas, en la época de Cimón, que también se apoyaba en la tradición de Teseo como benefactor heroico. La Historia Augusta dice de él que servos a dominis occidi vetuit y lo califica como amante de la plebe. ${ }^{205}$ El texto continúa con una referencia a su afición a viajar, es decir que se inserta en los rasgos más característicos del emperador, por los que era alabado y criticado.

Plutarco pone como ejemplo la Atenas clásica tanto a Adriano como a Trajano, a este último en Dichos de reyes y emperadores. Todo el escrito está dedicado a ello. Escribió las Vidas seguramente antes de 117 d.C., cuando comienza en reinado de Adriano.

\section{Referencias bibliográficas}

Ampolo, C. (1988): Le vite di Teseo e di Romulo, Milano.

Beazley, J. D. (1963): Attic Red-Figure Vase-Painters, Oxford, 2 vols.

Bernabé, A. (ed.), (2005): Aristóteles. Constitución de los atenienses, Madrid.

Beschi, L. - Musti, D. (1990): Pausania. Guida della Grecia. I - L'Attica, Torino.

Birley, A. (2003): Adriano (=Colección Atalaya 142), Barcelona.

Chamoux, F. (1992): Pausanias. Description de Grèce. I, Paris.

Citro, S. (2017): "Consigli per un imperatore: saggio di commento (Reg. et imp. Apoht.172B-E)", Ploutarchos 14, 3-34.

Cohen, B. (2001): "Ethnic Identity in Democratic Athens and the Visual Vocabulary of Male Costume", [en] Malkin (ed.), 2001, 235-274.

\footnotetext{
200 Plácido 2008, 15-20

201 Plácido 1995a, 249.

202 Plácido 1995a, 251.

203 Plácido 1997.

204 Cortés Copete 1997.

205 SHA Hadrianus 18.7 y 17.8, respectivamente.
} 
Cortés Copete, J. M. (1997): "Problemas ideológicos de la integración griega en el Imperio", [en] D. Plácido - J. Alvar - J. M. Casillas - C. Fornis (eds.), Imágenes de la polis (=ARYS 6), Madrid, 269-282.

Costa, V. (a.c.), (2007): Filocoro di Atene. I - Testimonianze e Frammenti del'Atthis, Tivoli.

Dowden, K. (1992): The Uses of Greek Mythology, London (http://dx.doi. org/10.4324/9780203316269).

Euben, J. P. (1986): Greek Tragedy and Political Theory, Berkeley-Los Angeles-London.

Flacelière, R. (1957) Plutarche. Vies I, Paris.

Fontenrose, J. (1978): The Delphic Oracle. Its Responses and Operations. With a Catalogue of Responses, Berkeley-Los Angeles-London.

Fowler, R. L. (2000): Early Greek Mythography. I - Texts, Oxford.

Gallego, J. (2018): La anarquía de la democracia. Asamblea ateniense y subjetivación del pueblo (=Estudios del Mediterráneo Antiguo, PEFSCEA 14), Buenos Aires.

García Romero, F. (2013): "Su Forbante, pugile e lottatore", [en] P. Mauritsch - C. Ulf (eds.), Kultur(en) Formen des Alltäglichen in der Antiken, festschrift für I, Weiler, Graz, 445-456.

Garland, R. (1992): Introducing New Gods. The Politics of Athenian Religion, London.

Gomme, A. W. - Andrewes, A. - Dover, K. J. (1945-1981): A Historical Commentary on Thucydides, Oxford, 5 vols.

Gonzalès, A. (2018): "Peut-on penser l'esclavage quand on est stoîcien?”, [en] R. Martínez Lacy (coord.), Hermenéutica de la esclavitud. Actas del XXXVII coloquio del GIREA, Besançon, 29-55.

Grethlein. J. (2014): “The Many Faces of the Past in Archaic and Classical Greece”, [en] K. Raaflaub (ed.), Thinking, Recording, and Writing History in Ancient World, Chichester, 234-255 (http://dx.doi.org/10.1002/9781118412541).

Harding, $\mathrm{P}$.

(1974): “Androtion's View of Solon's Seisachtheia”, Phoenix 28/3, 282-289 (http:// dx.doi.org/10.2307/1087503).

(1994): Androtion and the Atthis. The Fragments Translated with Introduction and Commentary, Oxford.

Hobsbawn, E. - Ranger, T. (eds.), (1983): The Invention of Tradition, Cambridge (https://doi. org/10.1017/CBO9781107295636).

Jacoby, F.

(1949): Atthis. The Local Chronicles of Ancient Athens, Oxford.

(1962): Die Fragmente der griechischen Historiker, Leiden.

Klein, N. (2010): La doctrina del shock. El auge del capitalismo del desastre, Barcelona.

Lambert, S. (2010): "Connecting with the Past in Lycourgean Athens: An Epigraphical Perspective", [en] L. Foxhall - H. J. Gehrke - N. Luraghi (eds.), Intentional History. Spinning Time in Ancient Greece, Stuttgart, 225-238.

Levick, B. (2000): “Greece and Asia Minor”, CAH XI, 604-634 (http://dx.doi.org/10.1017/ CHOL9780521263351.021).

Loraux, N.

(1973): "Marathon ou l'histoire idéologique. A propos des paragraphes 20 à 26 de l'oraison funèbre en l'honneur des soldats qui allèrent au secours des Corinthiens (attribuée à Lysias)", Revue des Études Anciennes 75, 13-42 (https://doi.org/10.3406/ rea.1973.3933).

(1981): L'invention d'Athènes. Histoire de l'oraison funèbre dans la cité classique (=École des Hautes Études en Sciences sociales. Centre de Recherches Historiques. Civilisations et sociétés 65), Paris. 
Mactoux, M. M. (1988): "Lois de Solon sur les esclaves et formation d'une société esclavagiste", [en] T. Yuge - M. Doi (eds.), Forms of Control and Subordination in Antiquity, Leiden, 331-354.

Malkin, I. (ed.), (2001): Ancient Perceptions of Greek Ethnicity (=Center for Hellenic Studies. Colloquia 5), Cambridge.

Martín, F. (1982): La documentación griega de la cancillería del emperador Adriano (=Colección Mundo Antiguo 5), Pamplona.

Mazzarino, S. (1974): Il pensiero storico classico, Roma.

Morgan, K. A. (1998): "Plato's Atlantis Story and Fourth-Century Ideology", Journal of Hellenic Studies 118, 101-118 (https://doi.org/10.2307/632233).

Musti, D. (2000): Demokratia. Orígenes de una idea (=Filosofía y pensamiento. Ensayo 164), Madrid.

Musti, D. - Torelli, M. (1991): Pausania. Guida della Grecia. IV - La Messenia, Milano.

Nielsen, T. H. (2007): Olympia and the Classical Hellenic States City-Culture (=Historiskfilosofiske meddelelser 96), København.

Nouhaud, M. (1982): L'utilisation de l'histoire par les orateurs attiques (=Collection d'études anciennes 91), Paris.

O'Sullivan, L. (2001): "Pollux and the Nomophylakes of Demetrius of Phalerum", Journal of Hellenic Studies 121, 51-62 (https://doi.org/10.2307/631827).

Parke, H. W. (1977): Festivals of the Athenians, Ithaca, NY.

Plácido, D.

(1992): "La ley olearia de Adriano: la democracia ateniense y el imperialismo romano", Gerión 10, 171-179.

(1993): “Las razones del poder democrático ateniense", IIes. Jornades de debat. El poder de l'estat: evoluciò, força o raó, Reus, 11-27.

(1994): “Teseo: la tradición y la renovación en la religiosidad de Plutarco", [en] M. García Valdés (ed.), Estudios sobre Plutarco: ideas religiosas. Actas de III Simposio Internacional sobre Plutarco, Oviedo, 30 de abril a 2 de mayo de 1992, Madrid, 137143.

(1995a): "Las transformaciones de la ciudad de Atenas desde el inicio de la intervención romana hasta la crisis del siglo III", Kolaios 4, 241-251.

(1995b): "La demokratía de Plutarco", [en] I. Gallo - B. Scardigli (a.c.), Teoria e prassi politica nelle opere di Plutarco. Atti del V Convegno plutarcheo (Certosa di Pontignano, 7-9 giugno 1993), (=Collectanea 8), Napoli, 383-389.

(1997): "Las intervenciones del poder en la imagen del ágora de Atenas", [en] A. J. Domínguez - C. Sánchez (eds.), Arte y poder en el mundo antiguo, Madrid, 177-188.

(2002): "Guerre et marchés d'esclaves dans la Grèce classique", [en] M. Garrido-Hory (ed.), Routes et marchés d'esclaves. Actes du 26 colloque du GIREA, Besançon, 27-29 septembre 2001, Paris, 21-28.

(2004): “Un siglo de cambios", [en] J. M. Cortés Copete - E. Muñiz Grijalvo (eds.), Adriano Augusto, Sevilla, 19-33.

(2008): "La ecúmene romana: espacios de integración y exclusión", Studia Historica. Historia Antigua 26, 15-20.

(2013): "Notas para un comentario histórico a Heraclidas de Eurípides", [en] L. M. Pino

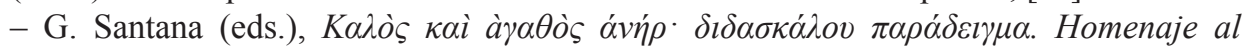
profesor Juan Antonio López Férez, Madrid, 657-664.

Podlecki, A. J. (1971): “Cimon, Skyros and Theseus' Bones”, Journal of Hellenic Studies 91, 141-3 (https://doi.org/10.2307/631382). 
Radt, S. (2008): Strabons Geographika. VII (Buch IX-XIII Kommentar), Göttingen.

Raaflaub, K. A. - van Wees, H. (eds.), (2009): A Companion to Archaic Greece, Malden (http://dx.doi.org/10.1002/9781444308761).

Robertson, N. (1988): "Melanthus, Codrus, Neleus, Caucon: Ritual Myth as Athenian History", Greek, Roman and Byzantine Studies 29, 201-261.

Saxonhouse, A. W. (1986): "Myths and the Origins of Cities: Reflections on the Autochthony in Euripides' Ion", [en] Euben (ed.), 1986, 252-273.

Scheppen, G. (ed.), (1998): Felix Jacoby. Die Fragmente der Griechischen Historiker, continued, IV Biography and Antiquarian Literature. IA Biography, 1: The Pre-Hellenistic Period, Leiden.

Smart, J. S. (1967): “Kimon's Capture of Eion”, Journal of Hellenic Studies 87, 136-8 (http:// dx.doi.org/10.2307/627817).

Travlos, J. (1980): Pictorial Dictionary of Ancient Athens, New York.

Valdés, $\mathrm{M}$.

(2000): "El Theseion, lugar de refugio de esclavos: sus orígenes y función en el 'ágora vieja’ de Atenas", [en] M. M. Myro - J. M. Casillas - J. Alvar - D. Plácido (eds.), Las edades de la dependencia durante la Antigüedad (=ARYS 9), Madrid, 41-54.

(2012): La formación de Atenas. Gestación, nacimiento y desarrollo de una polis (1200/1110- 600 a.C.), Zaragoza.

Volpe, P. (2017): “La concezione dell'esilio nell'opera di Plutarco”, Ploutarchos 14, 107116.

Wallace, S. (2011): "The Significance of Plataia for Greek Eleutheria in Early Hellenistic World", [en] A. Erskine - L. Llewellyn-Jones (eds.), Creating a Hellenistic World, Swansea, 147-176 (https://doi.org/10.2307/j.ctvvnbm8).

Walbank, F. W. (1962): "Polemic in Polybius", Journal of Roman Studies 52, 1-12 (http:// dx.doi.org/10.2307/297872).

Waterfields, R. - Gregory, A. (2008): Plato's Timaeus and Critias, Oxford.

Wiesehöfer, J. (2009): “Greeks and Persians”, [en] Raaflaub - van Wees (eds.), 2009, 162186.

Wycherley, R. E. (1978): The Stones of Athens, Princeton, NJ. 